\title{
Fine Structure of Thiobacillus novellus
}

\author{
By M. KOCUR, T. MARTINEC AND K. MAZANEC \\ Czechoslovak Collection of Microorganisms, and Department of Histology \\ and Embryology, J. E. Purkyně University, Brno, Czechoslovakia
}

(Accepted for publication 22 January 1968)

\begin{abstract}
SUMMARY
The study of ultrathin sections of Thiobacillus novellus has shown that it has a structure similar to that of $T$. thiooxidans and other Gram-negative bacteria. The cell wall showed a multilayered structure and varied in thickness between 250 and $350 \AA$. The cytoplasmic membrane and $70 \AA$ thick. On certain media a capsule was formed. The cytoplasm contained ribosomes and polymetaphosphate granules. The structure of the nuclear material was similar to that observed in other bacteria.
\end{abstract}

\section{INTRODUCTION}

Thiobacillus novellus Starkey 1935 represents an exception among species of the genus Thiobacillus. While the other species of the genus are both motile and obligate autotrophic $T$. novellus is non-motile and facultative autotrophic.

Sijderius (1946) was of the opinion that Thiobacillus novellus was identical with Micrococcus denitrificans. The mentioned species, however, differ both in their ultrastructure (Kocur, Martinec \& Mazanec, 1968) and in their \% GC values in the deoxyribonucleic acid (Boháček, Kocur \& Martinec, 1965). Therefore they cannot be considered as identical.

The purpose of this paper was to give a description of the fine structure of Thiobacillus novellus and compare it with the structures of similar organisms already described by other authors.

\section{METHODS}

Organism. The strain Thiobacillus novellus CCM 1077 (ATCC 8093) used in the present study came from the Czechoslovak Collection of Microorganisms, J. E. Purkyne University, Brno. The cells were grown on two different media: on the medium for autotrophic growth of T. novellus recommended by Santer, Boyer \& Santer (1959) and on the medium of Chang \& Morris (1962).

Electron microscopy. After $24 \mathrm{hr}$ cultivation at $30^{\circ}$, the cells were flushed with saline, washed three times and centrifuged for $5 \mathrm{~min}$. After $2 \mathrm{hr}$ fixation with $\mathrm{I} \%$ solution of $\mathrm{OsO}_{4}$ in phosphate buffer at $\mathrm{pH} \mathrm{7.3}$ according to Millonig (I962), the cells were flushed with appropriate buffer and refixed with $10 \%$ neutral formol at $4^{\circ}$ for $\mathrm{I}$ hr. After having been washed with saline the cells were centrifuged and embedded in $\mathrm{I} \cdot 3 \%$ agar and dehydrated with alcohol. The dehydrated blocks were embedded in Epon 812 according to the prescription of Luft (I96I). 
Ultrathin sections made with an ultramicrotome, type Tesla Bs 478 , were stained for $20 \mathrm{~min}$ with a $2 \%$ solution of uranylacetate $(\mathrm{pH} 5)$ and for 10 min with lead citrate according to Reynolds (1963). The sections were studied and photographed in an electron microscope, type Tesla Bs 413 A.

\section{RESULTS}

In the same preparation of Thiobacillus novellus two types of cells were observed: short rods, measuring 0.8 to $\mathrm{I} \times \mathrm{I} \cdot 7 \mu$ and longer ones, the size of which was $\mathrm{I} \times 3.5 \mu$. As can be seen from Pl. I, fig. I, 2 the cell wall (CW) has a multilayered structure characteristic of Gram-negative bacteria and its total thickness ranges from 250 to $350 \AA$ (see Pl. 3, fig. 5, 6).

On certain cultivating media a capsule was formed. When cultivated in the medium of Chang \& Morris (1962) the cell wall of Thiobacillus novellus was covered with a mucous layer the thickness of which ranged from 700 to $1000 \AA$ (Pl. 3, fig. 5 and 6). But when cultivated in the medium of Santer et al. (I959) it did not form a capsule (Pl. I, fig. I, 2; Pl. 2, fig. 3, 4; Pl. 3, fig. 7, 8).

The cytoplasmic membrane is a typical unit membrane $80 \AA$ in width and corresponds by its structure and thickness to other Gram-negative bacteria. It can best be seen in Pl. 2, fig. 4. The cytoplasm is of granular structure and contains: (i) electrondense particles-ribosomes (R); (ii) inclusions (P). No mesosomes were observed.

There occur frequently light areas in Thiobacillus novellus, looking like vacuoles situated either in the end (Pl. I, fig. I, 2) or in the central part of the organism (P1. 3, fig. 5). These areas are separated from the cytoplasm by a membrane.

The nuclear material of Thiobacillus novellus has a typical filamentous structure of highly varied course. It is clearly distinguishable from the granular cytoplasm by its light colour.

Division in Thiobacillus novellus proceeds in the same way as in other Gramnegative bacteria (Conti \& Gettner, 1962; Mahoney \& Edwards, 1966). Different stages of division are shown in P1. 3, fig. 7, 8. Plate 3, fig. 7, shows the early stage of division-the cytoplasmic membrane and the cell wall begin to invaginate into cytoplasm. As can be seen from Pl. 3, fig. 8, each daughter cell has its own continuous cytoplasmic membrane (see arrows), while the cell wall is common to both cells.

\section{DISCUSSION}

The results obtained in the present work showed that the cell-wall structure of Thiobacillus novellus is similar to that of other Gram-negative bacteria (Mahoney \& Edwards, I966; Remsen \& Lundgren, I966). At present, the fine structure of only a single species of the genus Thiobacillus, $T$. thiooxidans, is known (Mahoney \& Edwards, 1966). The comparison of its electron micrographs with those of $T$. novellus showed that these organisms have a similar cell structure. No differences in the cellwall structure explaining the different physiology of the facultative autotrophic $T$. novellus and the strict autotrophic $T$. thiooxidans were observed. $T$. novellus differs from $T$. thiooxidans only in its greater size, in non-flagellated cells which can be encapsulated under certain conditions.

The internal structure of both organisms is similar. We found in Thiobacillus novellus large electron-dense bodies similar to those observed by Mahoney \& Edwards 
Journal of General Microbiology, Vol. 52, No. 3

Plate 1
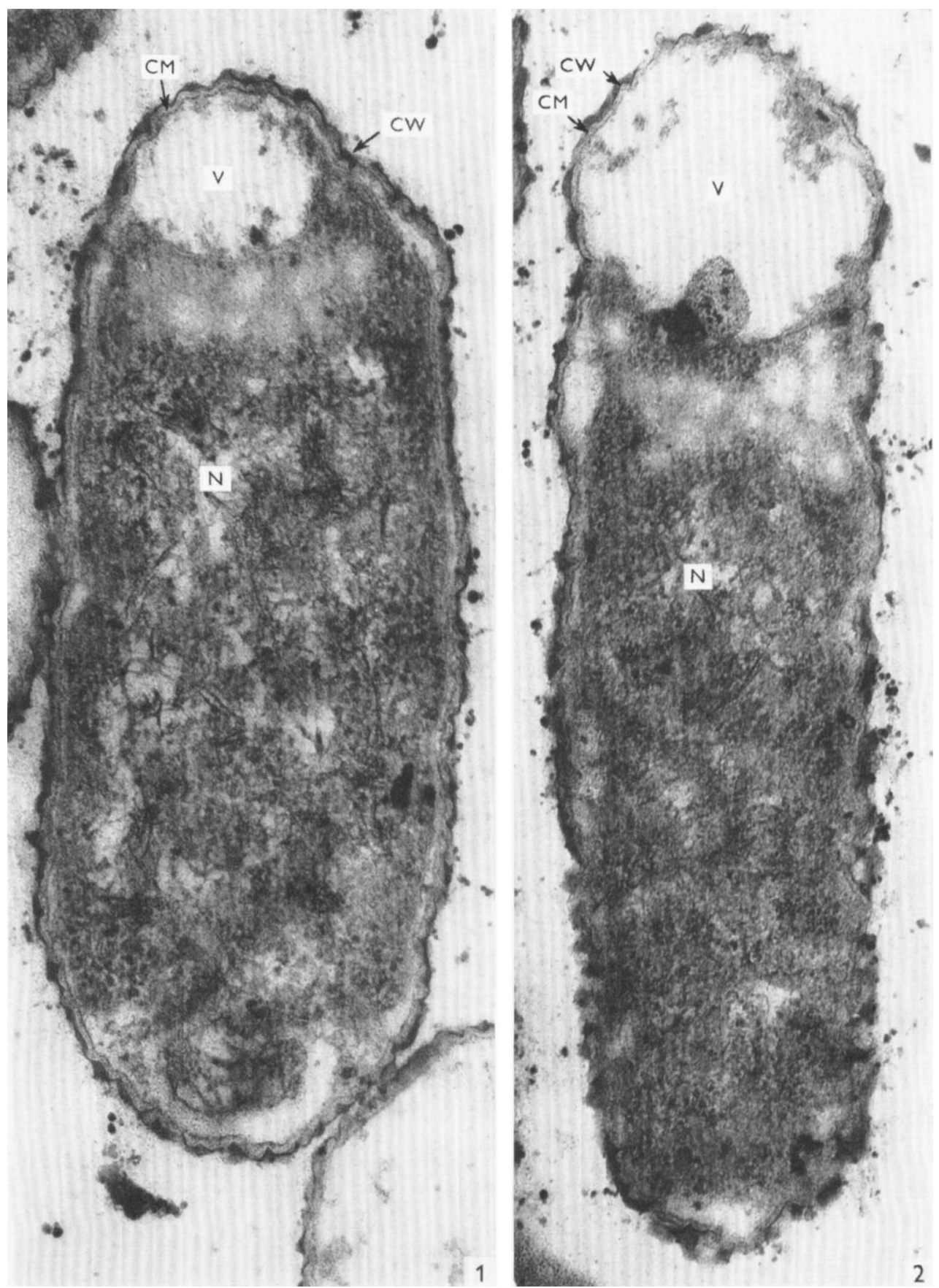

M. KOCUR, T. MARTINEC AND K. MAZANEC

(Facing p. 344) 
Journal of General Microbiology, Vol. 52, No. 3

Plate 2
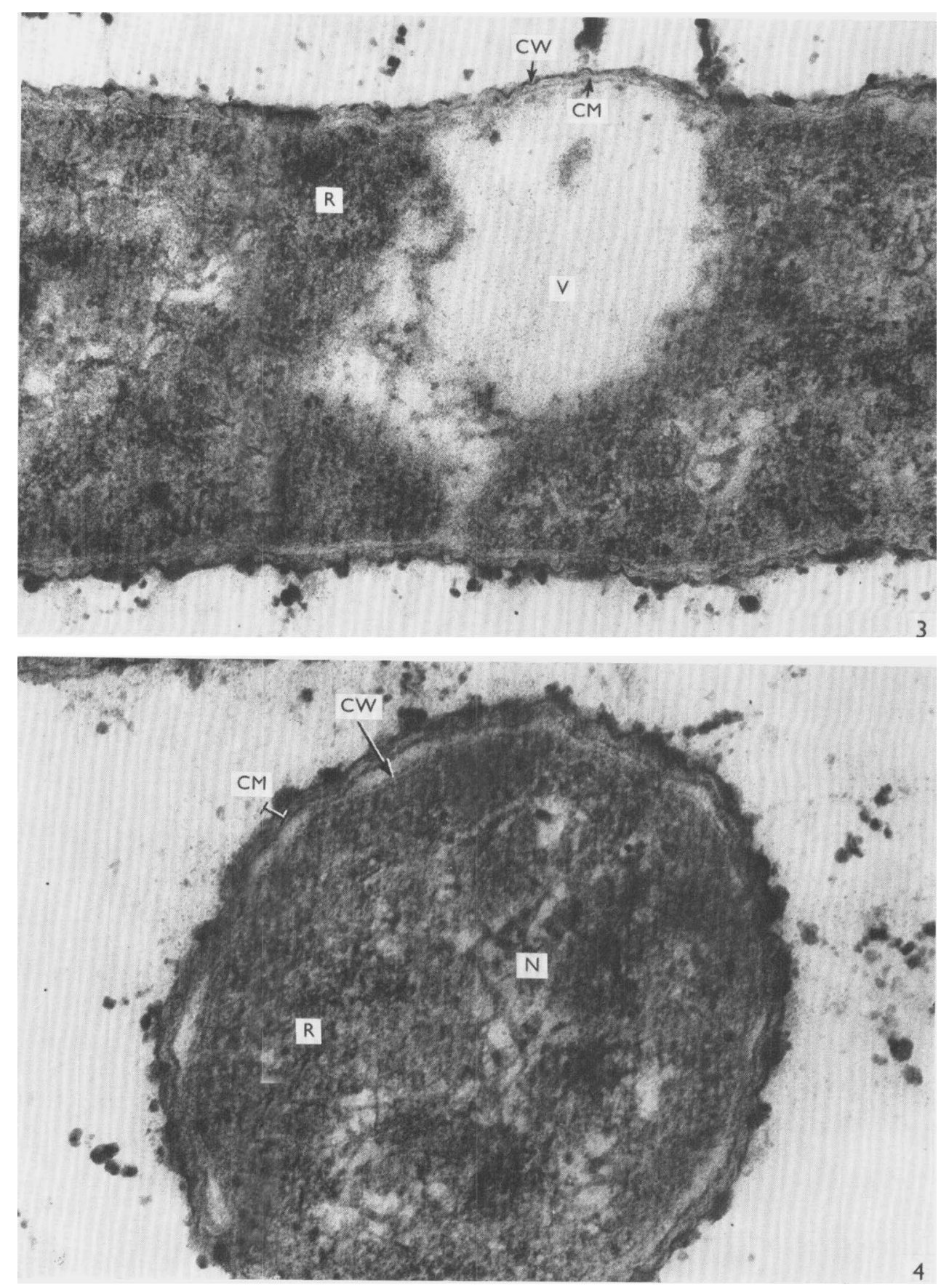

M. KOCUR, T. MARTINEC AND K. MAZANEC 

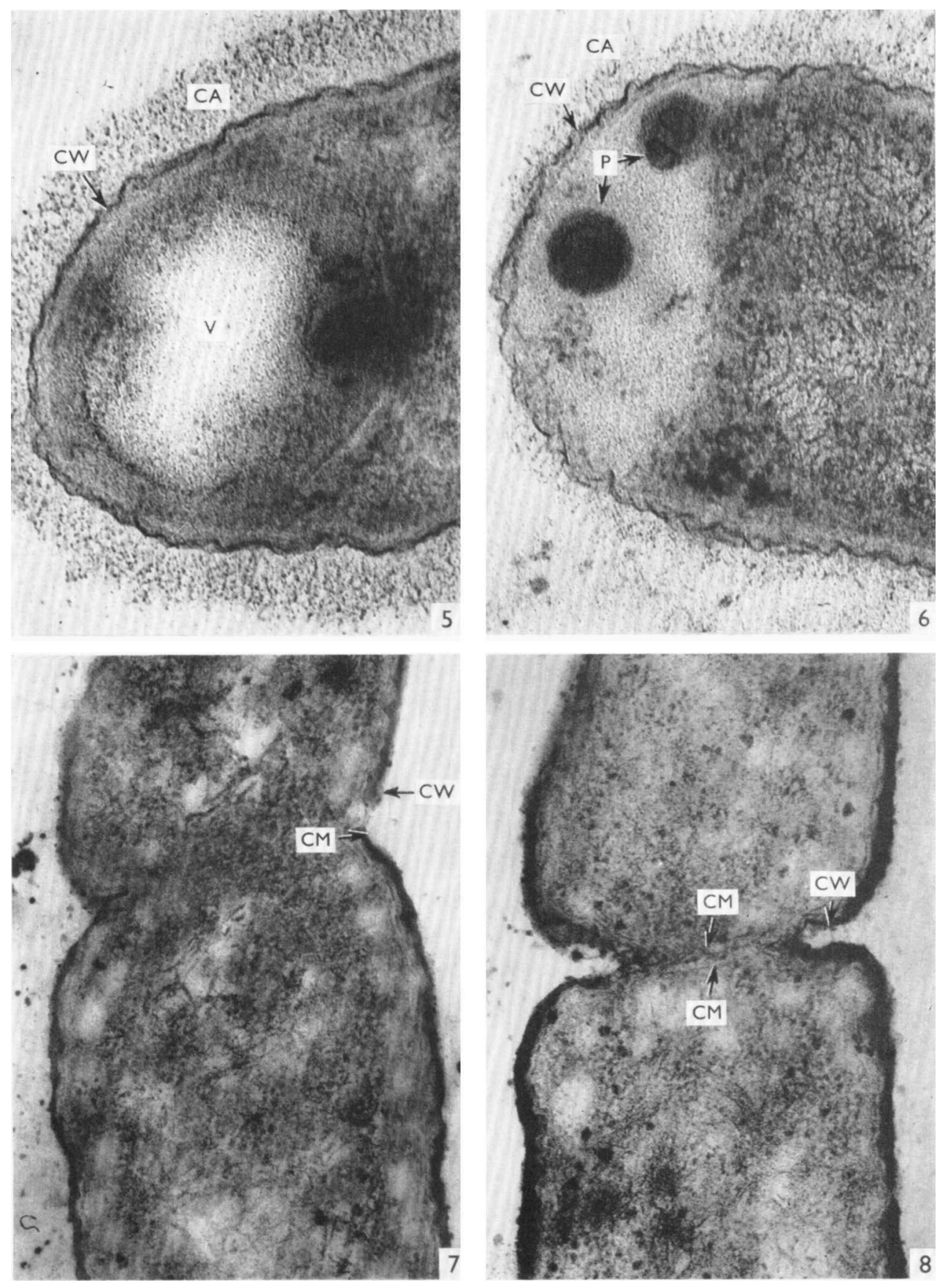

M. KOCUR, T. MARTINEC AND K. MAZANEC 

(1966) in T.thiooxidans. These osmiophilic bodies are most probably composed of polymetaphosphate. As for the light areas occurring in $T$. novellus, these are considered to be artifacts produced by plasmolysis as they are situated between the cell wall and the cytoplasmic membrane. It is known that plasmolysis can occur in various stages of preparation of the blocks for ultrathin sections.

\section{REFERENCES}

BOHÁČEK, J., KocuR, M. \& MARTINeC, T. (I965). Deoxyribonucleic acid base composition and taxonomy of the genus Micrococcus. Publ. Fac. Sci. Univ. J. E. Purkyně, Brno, K 35, 3 I 8.

ChANG, J. P. \& Morris, J. G. (1962). Studies on the utilization of nitrate by Micrococcus denitrificans. J. gen. Microbiol. 29, $30 \mathrm{I}$.

ContI, S. F. \& GeTtNer, M. E. (1962). Electron microscopy of cellular division in Escherichia coli. J. Bact. 83,544 .

Kocur, M., MARTINEC, T. \& MAZANEC, K. (I968). Fine structure of Micrococcus denitrificans and Micrococcus halodenitrificans in relation to their taxonomy. Antonie van Leeuwenhoek 34, 19.

LuFT, J. L. (1961). Improvements in epoxy resin embedding methods. J. biophys. biochem. Cytol. 9 , 409.

MAHONEY, R. P. \& EDWARDS, M. R. (1966). Fine structure of Thiobacillus thiooxidans. J. Bact. 92, 487.

MilLoNiG, G. (1962). Further observation on a phosphate buffer for osmium solution in fixation. In Breese, S. S., Jun. (ed.), Electron Microscopy, 5th int. Congr., Philadelphia, Pa. p. P-8. New York and London: Academic Press.

Remsen, Ch. \& Lundgren, D. G. (1966). Electron microscopy of the cell envelope of Ferrobacillus ferrooxidans prepared by freeze-etching and chemical fixation techniques. J. Bact. 92, I765.

REYNOLDS, E. S. (1963). The use of lead citrate at high $\mathrm{pH}$ as an electron opaque stain in electron microscopy. J. Cell Biol. $\mathbf{1 7}, 208$.

SANTER, M., BOYER, J. \& SANTER, U. (1959). Thiobacillus novellus. I. Growth on organic and inorganic media. J. Bact. 78, 197.

Starkey, R. L. (1935). Isolation of some bacteria which oxidize thiosulphate. Soil Sci. 39, 197.

SuJDerius, R. (1946). Heterotrophe bacteriën, die thiosulfaat oxydeeren. Thesis, University of Amsterdam, The Netherlands.

\section{EXPLANATION OF PLATES}

\section{Plate I}

Fig. I, 2. Longitudinal section showing cell wall (CW), cytoplasmic membrane (CM), nuclear material $(\mathrm{N})$, vacuole-like area (V). Fig. $1, \times 95000$; fig. $2, \times 75000$.

\section{Plate 2}

Fig. 3, 4. Longitudinal and cross-sections showing cell wall (CW), cytoplasmic membrane (CM), nuclear material $(\mathrm{N})$ and ribosomes (R). Fig. 3, × 75,000; fig. 4, $\times 125000$.

\section{Plate 3}

Fig. 5, 6. Portion of cells showing capsules (CA), cell wall (CW), cytoplasmic membrane (CM), polymetaphosphate granule $(\mathrm{P})$ and vacuole-like area (V). Fig. $5, \times 85,000$; fig. $6 \times 85,000$.

Fig. 7, 8. Portion of cells showing various stages of cell division. Cell wall (CW), cytoplasmic membrane (CM). Fig. $7, \times 75,000 ;$ fig. $8, \times 75,000$. 